\title{
Diversity, structure and composition of pteridophyte in varying habitats in Karimun Besar Island, Riau Islands Province, Indonesia
}

\author{
NERY SOFIYANTI", DYAH IRIANI, IKHWAN TAUFIK, MAYA SARI, ANDRE IRAWAN, FARID M. SYAUQI \\ Department of Biology, Faculty of Mathematics and Natural Sciences, Universitas Riau. Jl. Pekanbaru-Bangkinang Km 12.5, Kampus Bina Widya, \\ Simpang Baru, Panam, Pekanbaru 28293, Riau, Indonesia. Tel.: +62-761-63273, ^email: nery.sofiyanti@lecturer.unri.ac.id
}

Manuscript received: 11 September 2021. Revision accepted: 17 October 2021.

\begin{abstract}
Sofiyanti N, Iriani D, Taufik I, Sari M, Irawan A, Syauqi FM. 2021. Diversity, structure and composition of pteridophyte in varying habitats in Karimun Besar Island, Riau Islands Province, Indonesia. Biodiversitas 22: 4847-4856. Biodiversity of small islands, particularly in tropical region, always encourages scientific curiosity. Such curiosity is much greater when the small island of interest has been through various land use changes, such as in Karimun Besar Island. This island is one of thousand islands in Riau Islands Province, Indonesia and poses different land uses. However, studies on the biodiversity of flora in this island have not been recorded, including for pteridophyte or fern members. This study aimed to examine the diversity, floristic structure and composition of pteridophyte at six different study sites in Karimun Besar Island representing varying habitat conditions (i.e., primary forest, secondary forest, rubber plantation, road side, coastal area and mined land. The sampling was collected by using transect method to measure density, dominance and frequency. A total of 32 species of pteridophytes were recorded from the six study sites that belong to two divisions, Polypodiophyta (31 species) and Lycophyta (1 species). The number of species of pteridophyte varied across the six habitats. The highest number of species (21) was found in primary forest, while the lowest ( 9 species) was found in rubber plantation. The dominant species for each study site were Taenitis blechnoides (Pteridaceae) (rubber plantation), Dicranopteris linearis (Gleicheniaceae) (secondary forest), Sticherus truncates (Gleicheniaceae) (primary forest), Pteridium caudatum (Dennstaedtiaceae) (road side), Achrosticum aureum (Pteridaceae) (coastal area) and Nephrolepis hirsutula (Nephrolepidaceae) (mined land). The result of this study provides the first data of fern in Karimun Besar Island that support pivotal information on the biodiversity of small islands in tropical region.
\end{abstract}

Keywords: Fern, Karimun, pteridophyte

Abbreviations: Cov: coverage, NP: Number of plot, NI: Number of individuals, RP: Rubber plantation, SF: Secondary forest, PF: Primary forest, RS: Road side, CA: Coastal area, ML: Mined land

\section{INTRODUCTION}

Riau Islands Province is an archipelagic province in Indonesia comprising of thousand islands located in coastal area eastern of Sumatra. It borders with the Riau Province to the west, Singapore to the north, and South China Sea to the south. According to Guo et al. (2015), oceanic islands have specific environmental and bio-geographical characteristics because of isolation, resulting in unique biological diversity (both plants and animals) which is usually different with mainland (Hortal et al. 2009).

Floristic inventory is an effort to investigate and compile data and information of flora in a specific area (Badshah et al. 2013). It is fundamental for understanding the status of species diversity either in the past, current and future (Jayakumar et al. 2011). Floristic inventory is baseline information for assessing the state and dynamic of biodiversity to inform policies and management, for example conservation area establishment, threat assessment, species conservation, and so on (Amber et al. 2019). Nonetheless, such effort is lacking in the tropics more over in archipelagic region, so that the pattern of floristic richness of small tropical islands is poorly known and documented (Kreft et al. 2008).
Up to the present, there is no report on the floristic study in the islands of Riau Island Province including from Karimun Besar Island, one of the major islands in Riau Islands Province. This island has several types of ecosystems, ranging from coastal to hilly mountains that are inhabited by various flora including those from pteridophyte members or ferns and its allies. However, study on plant diversity, as well as pteridophyte, from Karimun Besar Island has never been recorded, nor from the other island at Riau Islands Province. Only limited studies on pteridophyte had been reported from coastal areas from nearby province (Riau Province) (Sofiyanti et al. 2019a; 2019b).

Pteridophyte is a plant group of seedless (Mir et al. 2015) and spore producing plant (Lashin 2012; Barrington et al. 2015; Gómez-Noguez et al. 2016; Sofiyanti et al. 2019b). According to Konrat et al. (2011), pteridophytes refer to vascular cryptogamic plants due to the presence of vascular bundle and spore. This group consists of Lycophytes and Monilophytes (Schneider and Eric 2016). The stem stele of Lycophytes have no leaf gap, while Monilophytes are characterized by the presence of leaf gap (Mir et al. 2015). Pteridophytes share the same characteristic with seed plant by having vascular bundle 
(Pigg and Rothwell 2001; Bondada et al. 2006; Kato and Ryoko 2011). Generally, the type of stele in pteridophyte member is protostele, in which the xylem is located in the center and surrounded by phloem (Sofiyanti et al. 2019). So far, about 12.000 species of pteridophyte have been identified (Della and Falkenberg 2019) and spread across many different habitats, from coastal regions (Medina et al. 1990) to mountains (Nettesheim et al. 2014).

Our preliminary study on Karimun Besar Island showed that this major island is occupied by various coastal flora, including pteridophyte members. We observed that ptheridophytes members were distributed on six different habitats in this island, i.e., rubber plantation, secondary forest, primary forest, road side, coastal area and mined land. However, there is no flora checklist, as well as pteridophytes, had been recorded from such varying habitats. Therefore, this study aimed to study the diversity, floristic structure and composition of pteridophyte at Karimun Besar Island across six different habitat types. The results of this study can enrich the existing floristic data at global and national levels, particularly regarding pteridophytes or ferns. The variation of habitat would provide insights of what habitat types are more preferred and less preferred by pteridophytes in the context of small island.

\section{MATERIALS AND METHODS}

\section{Study area and sampled sites}

Plant specimens were collected from six different study sites representing habitat types in Karimun Besar Island, Riau Islands Province (Figure 1). Six different habitat types were examined in this study, i.e., rubber forest, secondary forest, primary forest, road side, coastal area and mined land (Figure 2).

The first habitat type was rubber plantation (Figure 2.A). Rubber (Hevea brasilliensis Muel. Urg.; Euphorbiaceae), well-known as Brazillian rubber tree (Venkatachalam et al. 2013), is tree species that produce natural rubber (Pia and Konrad 2016). This rubber is obtained from tree latex (sap) and become one of important commodity crops in Indonesia. The rubber plantation in Karimun Besar Island, Riau Islands Province was initiated at 2007-2009 by the government. One of rubber plantation in Karimun District is located in Pongkar Village, Tebing Sub-district $\left(8 \mathrm{~m}\right.$ asl, coordinate $1^{\circ} 07^{\prime} 01.0^{\prime \prime} \mathrm{N}$ $\left.103^{\circ} 22^{\prime} 24.9^{\prime \prime} \mathrm{E}\right)$. This area is located on the side of main road from Pamak to Pongkar Village. In this study site, the average stem diameter of rubber trees on this area is ca. 47$52 \mathrm{~cm}$.

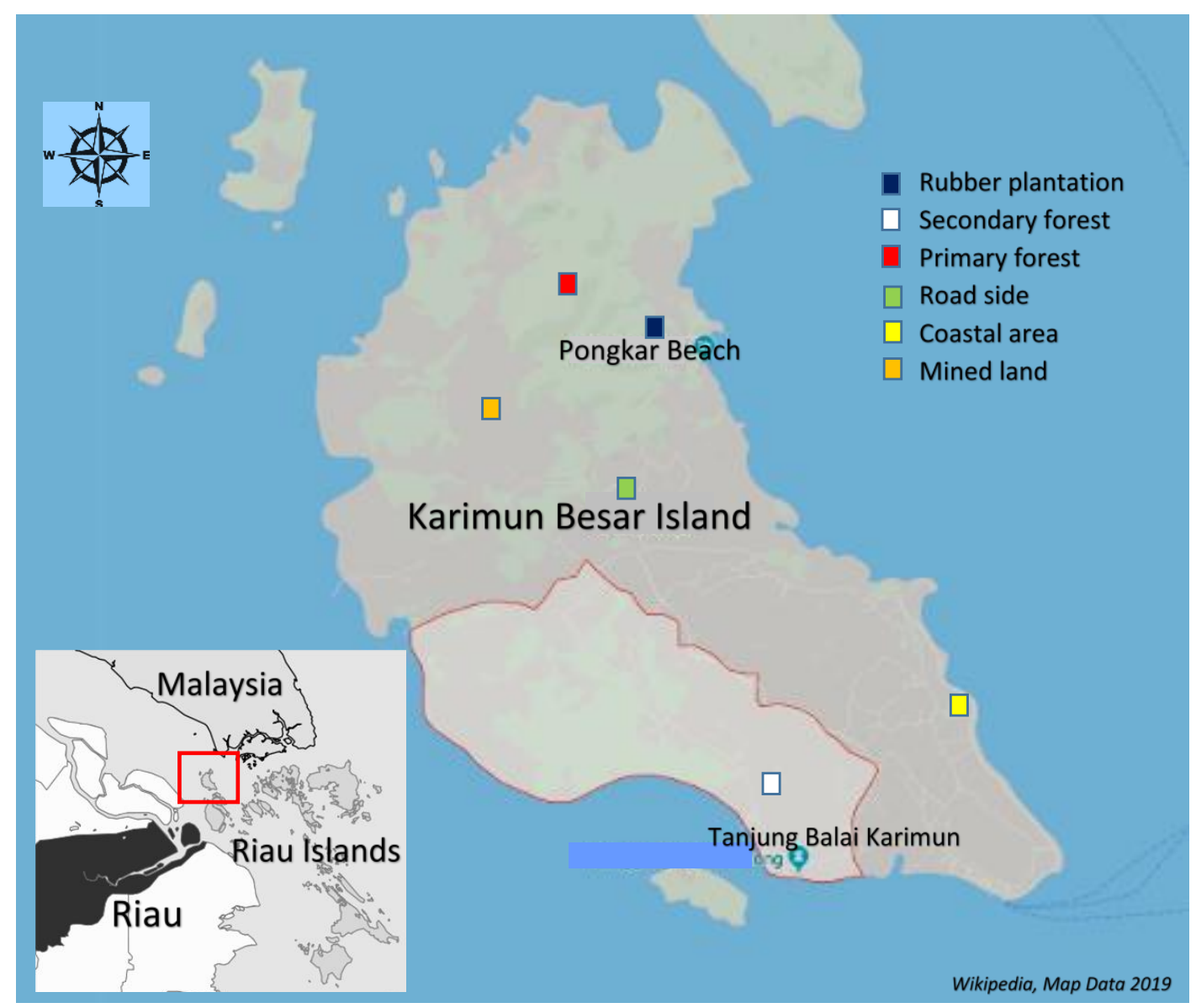

Figure 1. Map of study location in Karimun Besar Island, Riau Islands Province, Indonesia. (Map source Wikipedia and Map Data 2019) 


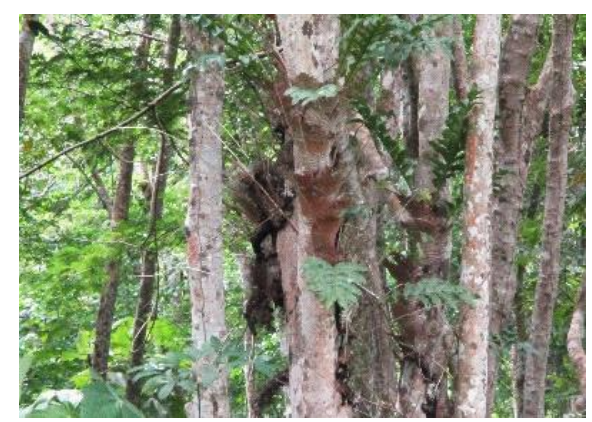

A

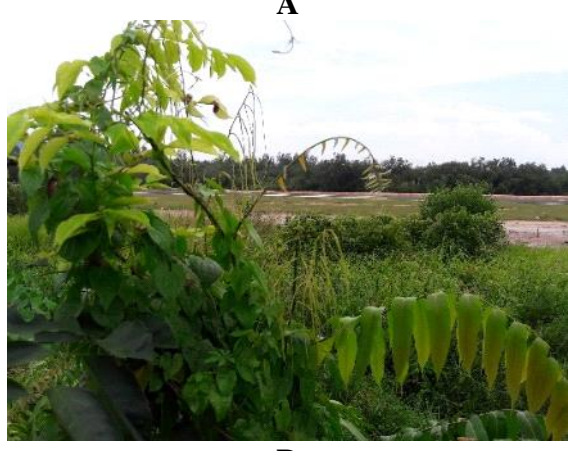

D

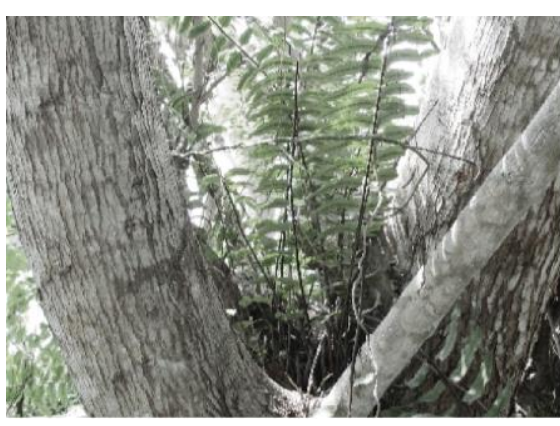

B

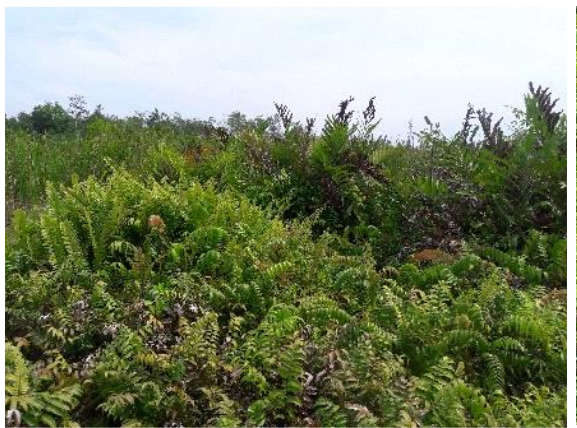

E

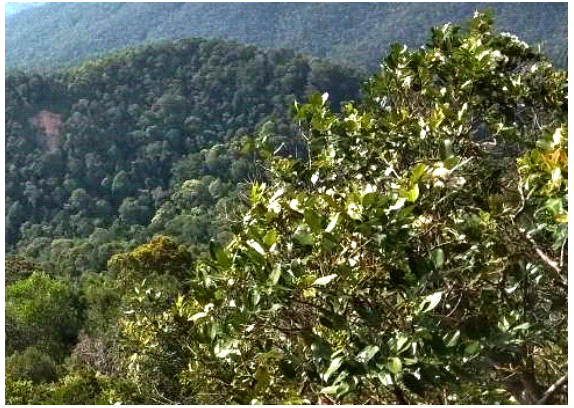

C

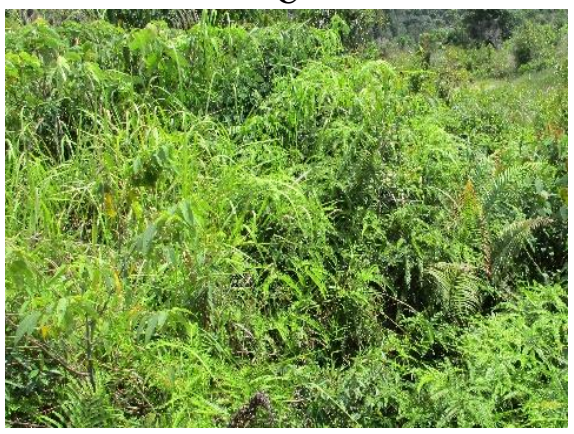

F

Figure 2. Six habitat types examined in this study. A. Rubber forest, B. Secondary forest, C. Primary forest, D. Road side, E. Coastal area and F. Mined land

Secondary forest in Karimun Besar Island was located in Tanjung Balai Karimun ( $13 \mathrm{~m}$ asl, coordinate $1^{\circ} 00^{\prime} 01 " \mathrm{~N}$ $\left.103^{\circ} 24^{\prime} 17^{\prime \prime E}\right)(2 B)$. This forest is located on the side of main road, and occupied by upper plant species from Spermatophyte such as Mango (Mangifera indica), rambutan (Nephelium sp.), Beringin (Ficus benjamina) and palm tree (Pinanga sp.). These species were cultivated by the district government as ornamental plants. The lower vegetation at secondary forest habitat consisted of grasses, liana and pteridophytes.

The primary forest in Karimun Besar Island is concentrated at Mt. Jantan, Pongkar (370 m, $1^{\circ} 05^{\prime} 41 " \mathrm{~N}$ $103^{\circ} 21^{\prime} 21$ "E) (Figure 2C). Primary forest shared the largest area in Karimun Besar Island compared to other habitat types that stretch up to $370 \mathrm{~m}$ asl. This forest still poses high plant diversity due to less anthropogenic activities. The common upper species in this primary forest belong to Dipterocarpaceae family. The jungle track in this forest was used for transect line. Pteridophytes in this forest share the same habitat with other lower spermatophytes.

Karimun Besar Island has many open-spaced areas at road ride (Figure 2D). Most of the sampled quadrats had no upper vegetation and were exposed to sun lights. In general, this habitat was occupied by many herbs and shrub species, including pteridophytes. In this site, the transects were placed at road side at Pamak street $(13 \mathrm{~m}$ asl, coordinate $1^{\circ} 02^{\prime} 52.3^{\prime \prime} \mathrm{N} 103^{\circ} 22^{\prime} 14.7^{\prime \prime E}$ ).

The transition area between land and sea is called coastal area. The structure and composition of vegetation at coastal area have important ecological function. As an island region, Karimun Besar Island is surrounded by coastal area (Figure 2E), and this area occupied by many species of mangrove, palm and other lower flora including pteridophyte. At some areas, the coastal area was dominated by giant fern species known as "Paku Laut Raksasa" or "Giant Sea Fern" (Acrostichum aureum). In this site, the transect was placed at Coastal Area of Teluk Uma (3 m asl $\left.1^{\circ} 02^{\prime} 59^{\prime \prime} \mathrm{N} 103^{\circ} 24^{\prime} 27^{\prime \prime E}\right)$.

The mined land (Figure 2F) in Karimun Besar Island is area that had been used for tin mining by PT. Timah Tbk, a state-owned corporation in Indonesia. Some of the areas were abandoned for many years and occupied by grasses, herbs and shrubs and only few species from tree plants. The transects were place at Darusalam $(17 \mathrm{~m}$ asl, $\left.1^{\circ} 04^{\prime} 04.9^{\prime \prime} \mathrm{N} 103^{\circ} 20^{\prime} 58.9^{\prime \prime} \mathrm{E}\right)$.

\section{Data collection procedure}

Sampling method used quadrat technique based on Schultz et al. (2009). A total of three transects were placed at each study site with five quadrats $(10 \times 10 \mathrm{~m})$ for each transect, resulted in total number of quadrat of 15 for each study site $\left(1500 \mathrm{~m}^{2}\right)$ (Table 1). All of the transects were established at each study site using purposive sampling method (Palys 2008). The number of individuals and number of quadrats that occupied by a species and coverage percentage were measured for each species.

\section{Sample collection and identification}

For each study site, all species found at every quadrat were collected and photographed. The samples were then put inside the plastic bag soaked with $70 \%$ alcohol and stored for herbarium specimens. The herbarium preparation was carried based on Kottapalli et al. (2016) and the specimens were then stored in Herbarium Riauensis. The fern identifications were mainly based on Piggot (1998) and Sofiyanti et al. (2015). We also use online identification 
guide using these following websites: https://rbgweb2.rbge.org.uk/thaiferns/Pages/ferns-of-thailand.htm, phytoimages.siu.edu. The accepted names and synonyms were checked at http://www.worldfloraonline.org/, https://www.gbif.org/species/3070795.

\section{Floristic structure and composition}

For each study site, the structure and composition of pteridophyte were described based on density, frequency and dominancy of each identified species. The number of total quadrats used in each study site was 15 , while total area studied was $1500 \mathrm{~m}^{2}$. The structural parameters were calculated based on Sharma (2006) and Khurma and Sibru (2015) as follow:

Density $(\mathrm{DE})=$ Number of individuals of species $\mathrm{i} /$ total studied area

Dominance $(\mathrm{DO})=$ Coverage of species $\mathrm{i} /$ total studied area

Frequency $(\mathrm{FR})=$ Number of quadrat in which species i occur / Number of total quadrat

\section{RESULTS AND DISCUSSION}

\section{Species diversity of pteridophytes}

A total of 32 pteridophyte species were recorded from six different habitat types in Karimun Besar Island, Riau Islands Province. They belong to two divisions, Polypodiophyta and Lycophyta. The Polypodiophyta division was dominant in this study with 3 orders, 12 families and 31 species. In contrast, only one Lycophyta species was recorded, i.e., Lycopodiella cernua. This species is the most common lycophyte group reported from Riau and Riau Islands Province (Sofiyanti et al. 2015; Sofiyanti 2019). Table 2 shows that a total of 9 species were only found in a habitat type, 7 species in two habitat types, 10 species in 3 habitat types, 1 species in 5 habitat types and 5 species in 5 habitat types. There was no species that distributed in all of six habitat types.

The number of species varied among the six habitat types. The highest number of species was found in primary forest (21 species) followed by road side (19 species). However, the species composition between these sites was different. Rubber plantation had the lowest number of species with a total of 9 pteridophyte species. Among 13 families in pteridophyte, Blechnaceae has the highest number of species (7 species, with two genera), followed by Pteridaceae family ( 6 species, 3 genera). This result is different with our previous study at Bengkalis Island, one of main island in coastal area of Riau Province (Sofiyanti et al. 2019).

The total number of species identified in all of study sites (32 species) is higher than in the nearby islands of Riau Province as reported from Bengkalis Island (Sofiyanti et al. 2019) and Rangsang Island (Sofiyanti et al. 2020), with a total of 22 and 23 species, respectively. Both islands have flatter topography than Karimun Besar Island. Otherwise, Karimun Besar Island poses various topography, from sea level to almost $400 \mathrm{~m}$ asl, with hilly topography in some locations. According to Hortal et al. (2009), the diversity of habitat will affect the species richness, the more habitat in a territory the more species are found. Furthermore, the effects of topography on structuring plant species had also been previously reported by Qi and Yang (1999), Punchi-Manage et al. (2013) and Wang et al. (2017).

Among 13 families recorded in this study, Blechnaceae had the highest number of species ( 7 species, with two genera), followed by Pteridaceae family (6 species, 3 genera). Blechnaceae members are characterized by having brownish red to dark red young fronds, with linear sori that parallel and adjacent to mid veins (Rolleri et al. 2010). This family comprises ca. 250 species (de Gasper et al. 2016) from ca. 29 genera. Blechnum is currently the rich-species genus in Blechnaceae with about 200 species (Rothfels et al. 2012; Perrie et al. 2014). The members of this genus are commonly found from sea level (Dittrich et al. 2015) to higher elevation. In this study, six out of seven Blechnaceae species belong to Blechnum, that distributed in four study sites, i.e., primary forest, road side, coastal area and mined-land. Stenochlaena palustris was only one species belong to Stenochlaena (Blechnaceae) found in this study. This species is the most common Stenochlaena species in Riau Islands and other Sumatera regions.

Pteridaceae is one of the largest pteridophyte family with up to 950 species worldwide, mostly terrestrial or epilithic, some epiphytic and rarely aquatic (Zhang et al. 2013). The members of this family have linear sori and lack of true indusium (replaced by the presence of pseudoindusium) (Kessler et al. 2017). A total of 4 genera were recorded in this study (Acrostichum, Adinatum, Pteris and Taenitis). Acrostichum and Pteris were only recorded in one study site (coastal area and road site, respectively), while Adiantum and Taenitis showed wider distribution in three study sites.

Table 1. List of study sites being sampled in this study

\begin{tabular}{lcl}
\hline \multicolumn{1}{c}{ Study sites } & $\begin{array}{c}\text { Number of quadrat } \\
\left(\mathbf{1 0} \mathbf{x} \mathbf{1 0} \mathbf{~ m}^{\mathbf{2}}\right)\end{array}$ & Note \\
\hline Rubber plantation & 15 & Code of transects RPPO1, RPPO2, RPPO3. Pongkar \\
Secondary forest & 15 & Code of transect SFTBK1, SFTBK3, SFTBK3 Tanjung Balai Karimun \\
Primary forest & 15 & Code of transects: PFMJA1, PFMJA2, PFMJA3 Mount Jantan \\
Road side & 15 & Code of transects RSPA1, RSPA2, RSPA3, Pamak \\
Coastal area & 15 & Code of transects: CATU1, CATU2, CATU3, Teluk Uma \\
Mined land & 15 & Code of transects: MLDA1, MLDA2, MLDA3, Darusalam \\
Total & 90 & \\
\hline
\end{tabular}


Table 2. List of identified species of pteridophytes in six habitat types in Karimun Besar Island, Riau Islands Province, Indonesia

\begin{tabular}{|c|c|c|c|c|c|c|c|c|}
\hline Divisi, Family & Species & $\mathbf{A B R}$ & $\mathbf{R P}$ & SF & PF & $\mathbf{R S}$ & $\mathbf{C A}$ & ML \\
\hline \multicolumn{9}{|l|}{ Lycophyta } \\
\hline \multicolumn{9}{|l|}{ Lycopodiales } \\
\hline Lycopodiaceae & Lycopodiella cernua (L.) Pic. Serm & LCE & - & - & - & + & - & + \\
\hline \multicolumn{9}{|l|}{ Polypodiophyta } \\
\hline \multicolumn{9}{|l|}{ Gleicheniales } \\
\hline \multirow[t]{2}{*}{ Gleicheniaceae } & Dicranopteris linearis (Burm. f.) Underw. & DLI & - & + & + & + & + & + \\
\hline & Sticherus truncatus (Willd.) Nakai & STR & - & - & + & - & - & - \\
\hline Matoniaceae & Matonia pectinata $\mathrm{R} . \mathrm{Br}$. & MAP & - & - & + & - & - & - \\
\hline \multicolumn{9}{|l|}{ Polypodiales } \\
\hline Aspleniaceae & Asplenium nidus L. & ANI & - & + & + & + & + & + \\
\hline \multirow[t]{7}{*}{ Blechnaceae } & Blechnum finlaysonianum Wall. & BFI & - & - & + & + & - & + \\
\hline & Blechnum occidentale L. & $\mathrm{BOC}$ & - & - & + & + & + & - \\
\hline & Blechnum orientale L. & BOR & - & - & - & + & + & + \\
\hline & Blechnum serrulatum Rich. & BSE & - & - & - & + & + & - \\
\hline & Blechnum sp1. & BL1 & - & - & - & + & - & + \\
\hline & Blechnum $\mathrm{sp} 2$ & BL2 & - & - & - & + & - & - \\
\hline & Stenochlaena palustris (Burm. f.) Bedd.* & SPA & - & - & - & + & + & - \\
\hline Davalliaceae & Davallia denticulata (Burm. f.) Mett. ex Kuhn & DDE & + & + & + & - & - & - \\
\hline Dennstaedtiaceae & Pteridium caudatum (L.) Maxon.* & PCA & - & + & + & + & + & + \\
\hline \multirow[t]{2}{*}{ Lindsaeaeceae } & Lindsaea ensifolia $\mathrm{Sw}$. & LEN & + & + & + & - & - & - \\
\hline & Schizoloma divergens (Hook. \& Grev.) Kuhn & SDI & + & - & - & - & - & - \\
\hline Nephrolepidaceae & Nephrolepis hirsutula (G. Forst) C. Presl & $\mathrm{NHI}$ & - & - & - & + & + & + \\
\hline \multirow[t]{3}{*}{ Polypodiaceae } & Drynaria quercyfolia (L.) J. Sm. & DQU & + & + & + & - & - & - \\
\hline & Microsorum punctatum (L.) Copel, & MPU & - & + & + & + & - & - \\
\hline & Pyrrosia piloselloides (L.) M.G. Price & PPI & + & + & + & + & - & - \\
\hline \multirow[t]{6}{*}{ Pteridaceae } & Acrostichum aureum $\mathrm{L}$. & AAU & - & - & - & - & + & - \\
\hline & Acrostichum speciosum Willd. & ASP & - & - & - & - & + & - \\
\hline & Adiantum latifolium Lamm. & ALA & + & - & + & + & - & - \\
\hline & Adiantum raddianum $\mathrm{C}$. Presl. & ARA & - & - & + & + & - & - \\
\hline & Pteris vitata $\mathrm{L}$. & PVI & - & - & - & + & - & - \\
\hline & Taenitis blechnoides (Willd.) Sw. & TBL & + & + & + & - & - & - \\
\hline \multirow[t]{2}{*}{ Thelypteridaceae } & Cyclosorus opulentus (Kaulf.) Nakaike & $\mathrm{COP}$ & - & + & + & - & - & - \\
\hline & Cyclosorus sp. & CYC & - & - & + & - & - & - \\
\hline \multicolumn{9}{|l|}{ Schizaeales } \\
\hline \multirow{5}{*}{ Lygodiaceae } & Lygodium circinatum (Burm. f.) Sw. & LYC & + & + & + & - & - & - \\
\hline & Lygodium japonicum (Thumb.) SW.* & LYJ & - & + & + & + & + & + \\
\hline & Lygodium longifolium (Willd.) Sw. & LYL & - & + & + & - & - & - \\
\hline & L ygodium microphyllum (Cav.) R. Br. & LYM & + & + & + & + & - & + \\
\hline & Number of species & 32 & 9 & 14 & 21 & 19 & 12 & 10 \\
\hline
\end{tabular}

Note: ABR: Abbreviation of species name, RP: Rubber plantation, SF: Secondary forest, PF: Primary forest, RS: Road side, CA: Coastal area, ML: Mined land

\section{Structure and composition}

The structure and composition of pteridophyte from six different habitat types in Karimun Besar Island, Riau Islands Province is presented in Figure 3. The number of individuals, number of plot in which species occur, percentage of coverage, density, dominance and frequency were calculated from each habitat type. The coverage was measured to know the canopy characterization (RamirezGracia et al. 2012). Density is total number of individuals of a species at studied area. The measurement of density is necessary to examine plant production (Liu et al. 2017). Dominance is indicated by the coverage of species, that estimated by the foliage that projected vertically down to the ground. According to Mullan and Reynolds (2010), plant dominance plays an important role in soil protection and evapotranspiration estimations of an area. While frequency indicates the number of quadrat in which a species occurs. Therefore, frequency reflects the distribution or spread of a species, whether it is distributed uniformly at examined area or clustered at part of certain quadrant (Liu et al. 2017).

\section{Rubber plantation}

Figure 3.A shows the floristic structure and composition of pteridophytes at rubber plantation. A total of nine species was recorded at this habitat type that belong to five families, i.e., Davalliaceae (1 species), Lindsaeaceae (2 species), Polypodiaceae (2 species), Pteridaceae (2 species) and Lygodiaceae (1 species). The number of species identified at rubber plantation was the lowest among the six habitat types examined. The study of Hidayat et al. (2008) and Singh et al. (2019) showed that the alteration of aboveground vegetation into rubber plantation gave significant impacts on belowground 
biodiversity. The lower diversity due to forest replacement by rubber plantation was also reported by Lan et al. (2017). According to Aratrakorn et al. (2006) and Singh et al.
(2019), forest alteration into plantation can cause an overall loss and extensive replacement of soil micro-and mesofaunal diversity.

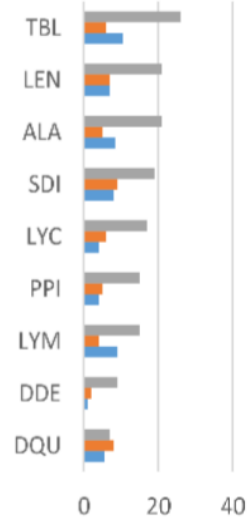

$\square \mathrm{NI}=\mathrm{NP} \cdot \mathrm{COV}$

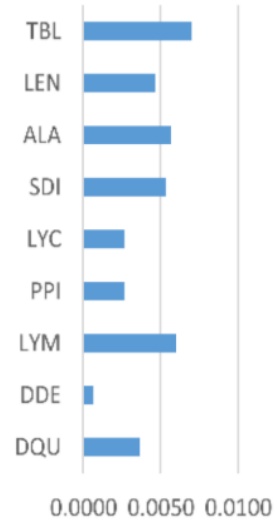

Dominance

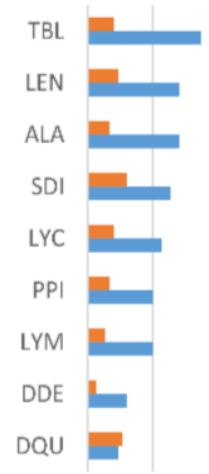

0.0001 .0002 .000

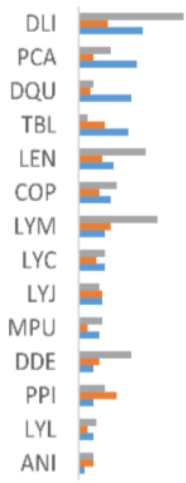

0

arequency $\mathbf{n}$ Density

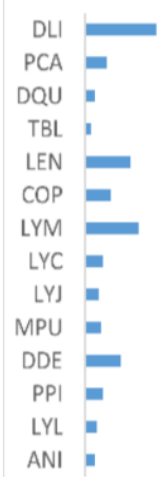

0
$\mathbf{A}$

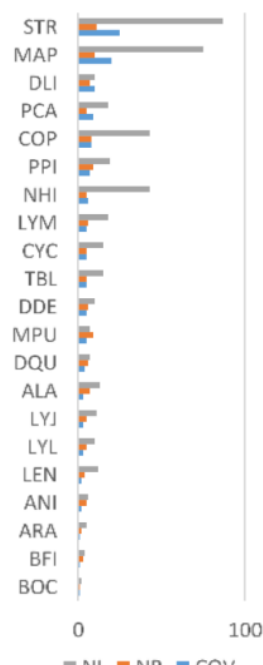

$\because \mathrm{NI}=\mathrm{NP}=\operatorname{cov}$

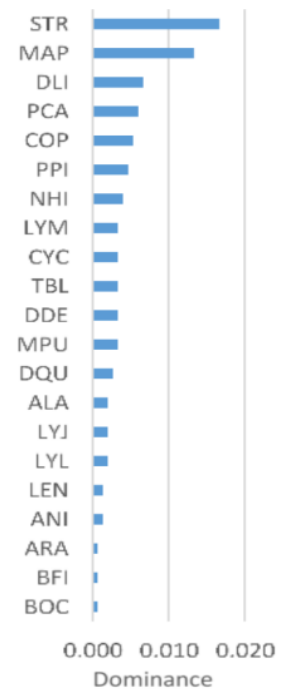

C

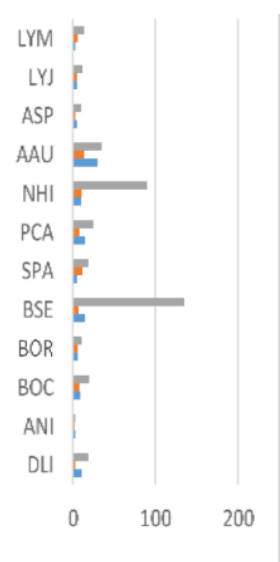

$\because \mathrm{NI}=\mathrm{NP}=\mathrm{COV}$

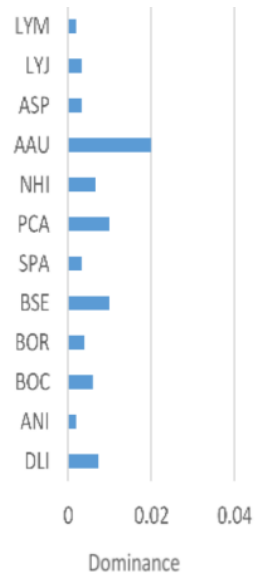

$\mathbf{E}$

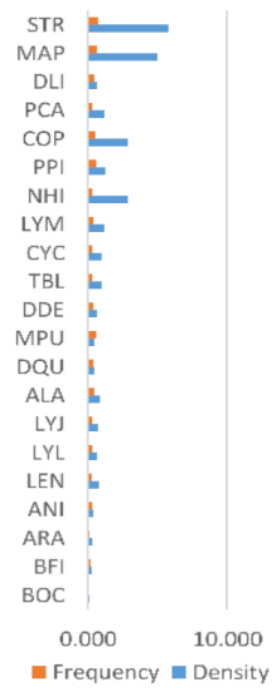

arequency $\mathbf{m}$ Density

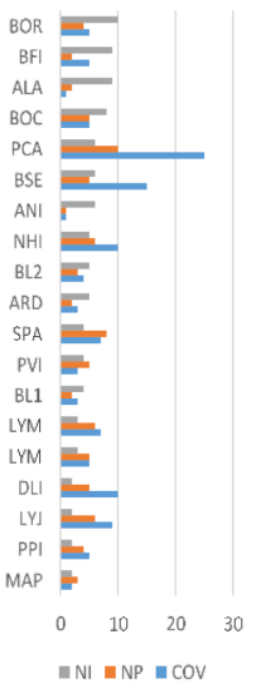

$\because \mathrm{NI} \pm \mathrm{NP} m \mathrm{COV}$

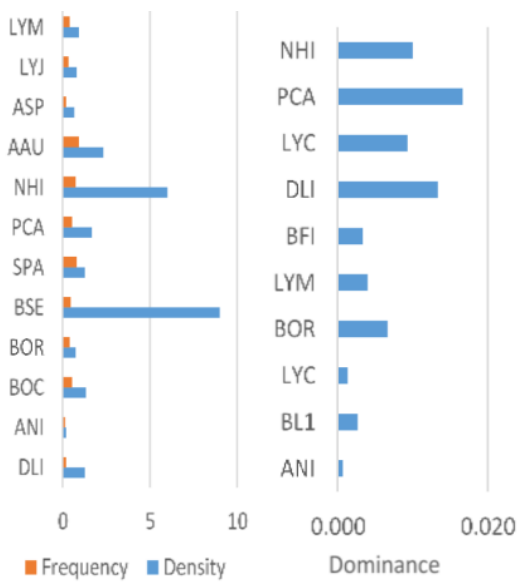

Dominance

B

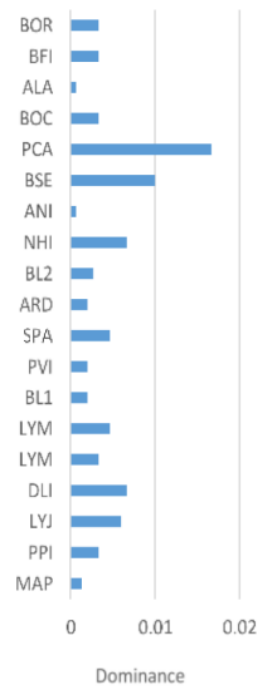

D

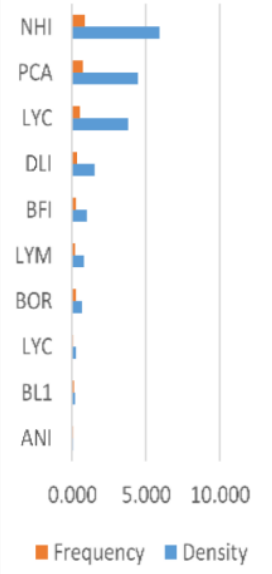

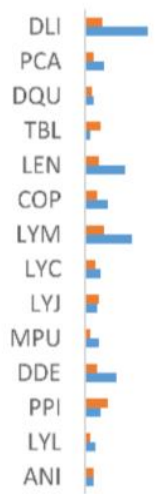

$0.000 \quad 5.000$

Erequency $\square$ Density

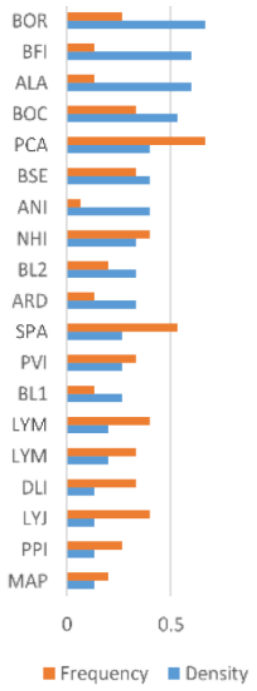

\section{$\mathbf{F}$}

Figure 3. Histogram of structure and composition of pteridophyte at six habitat types. A. rubber plantation, B. Secondary forest, C. Primary forest, D. Road side, E. coastal area, F. Mined land. (Cov: coverage, NP: Number of plot. NI: Number of individuals) 
In this site, Taenitis blechnoides (Pteridaceae) (Figure 4.A) had the highest number of individuals, coverage, density and dominance (Figure 3.A), while the highest number of plot in which species occur and frequency was Schizoloma divergen (Lindsaeaceae). This result indicated that this species is distributed more uniformly than Taenitis blechnoides because it was found in higher number of plot. Taenitis blechnoides is commonly found in forest floor or slightly shaded area, as reported by Saputra and Qotrunnada (2011) and forms a cluster on forest floor.

\section{Secondary forest}

Secondary forests in Karimun Besar Island were located at Pamak and Tanjung Balai Karimun. Most of the parts of this sites were occupied by agricultural crops that were sparsely planted. Therefore, this area was slightly shaded. A total of 14 fern species were identified in this habitat type, belonging to 8 families, i.e., Gleicheniaceae (1 species), Aspleniaceae (1 species), Davalliaceae (1 species), Denstaedtiaceae (1 species), Lindsaeaceae (1 species), Polypodiaceae (3 species), Pteridaceae (1 species) and Lygodiaceae (4 species). Figure 3.B shows the pteridophyte structure and composition in secondary forest.

In this study site, Dicranopteris linearis (locally known as Paku Resam) (Figure 4.B) shows the highest value of number of individuals, coverage percentage and density. This species is commonly found in open space area (Sofiyanti et al. 2019) or open canopy forest (Russell et al. 1998) with full sun or lightly shaded area (Perrie 2015). Dicranopteris linearis has creeping rhizome that continuously branched up to $10 \mathrm{~m}$ long and usually forms dense thicket. Therefore, the coverage of this species in this area was higher than other pteridophyte species. In this study, Dicranopteris linearis was mainly found at the margin of secondary forest with less coverage of upper vegetation.

However, the highest frequency in secondary forest was Pyrrosia piloselloides, occurred in 13 out of 15 studied quadrats. The various tree species occur in secondary forest provide a suitable habitat for this epiphytic species. This species was found at Mango (Mangifera indica), rambutan (Nephelium sp.), Beringin (Ficus benjamina) and Pinang (Pinanga sp.) tree. However, the coverage of Pyrrosia piloselloides is low due to its upward climbing habit and small leaves (ca. $1.5 \times 1.3 \mathrm{~cm}$ in sterile fronds, and 7-12 cm $\mathrm{x} 1 \mathrm{~cm}$ in fertile fronds. Therefore, this condition impacted to the low estimation of foliage that projected vertically down to the ground.

\section{Primary forest}

A total of 21 fern species were identified at this habitat type. These species belong to Lycopodiaceae (1 species), Glecheniaceae (2 species), Matoniaceae (1 species), Blechanceae (2 species), Aspleniaceae (1 species), Davalliaceae (1 species), Lindsaeaceae (1 species), Polypodiaceae (3 species), Pteridaceae (3 species), Thelypteridaceae (2 species) and Lygodiaceae (4 species). The number of species identified in primary forest was the highest among the other habitat types. Primary forest in Karimun Besar Island is located at hilly slope at Gunung Jantan, Pongkar. This topography impacts the environmental factor that suitable for many pteridophyte species. Besides that, primary forest in Karimun Besar Island had less anthropogenic pressure and make better environmental condition than other habitat types. The study by Fahreza and Qotrunnada (2011) showed that primary forest had higher diversity of pteridophyte than other disturbed areas.

Species with the highest value of all of parameter observed was Sticherus truncatus (Glecheniaceae) (Figure 4.C) and followed by Matonia pectinata (Matoniaceae) (Figure 4.D). Both species belong to Glechenialess order. Sticherus truncatus is commonly distributed at hill dipterocarp forest or montane forest with up to $1500 \mathrm{~m}$ asl (Go et al. 2012). This species was not found in the other habitat types that have lower altitude $(0-50 \mathrm{~m}$ asl). However, most of Glecheniales members will form the wide coverage at suitable habitat, because of the long creeping rhizome, with pseudo-or dichotomous rachis growth, as found in Sticherus truncatus and Matonia pectinata. The record of these species in Karimun Besar Island is the first record from Riau Islands Province as well as Riau Province.

\section{Road side}

The roadsides in Karimun Besar Island were mainly occupied by lower vegetation with few tree plants. In this habitat type, a total of 19 species of pteridophyte were recorded. These species belong to the families of Lycopodiaceae (1 species), Gleicheniaceae (1 species), Aspleniaceae (1 species), Blechnaceae (7 species), Denstaedtiaceae (1 species), Nephrolepidaceae (1 species) Polypodiaceae (2 species), Pteridaceae (3 species) and Lygodiaceae ( 2 species). The open area at road side is suitable habitat for many fern species with full sun tolerant.

In this site, Pteridium caudatum (Dennstaedtiaceae) (Figure 4.E) had the highest value of coverage, number of plot in which the species occur, dominance and frequency (presented in Figure 3.E). According to Marrs and Watt (2006), Pteridium caudatum prefers sunny condition for its growth. The high coverage of this species is due to its large habit. This species has long stipe (up to $100 \mathrm{~cm}$ or more) with broadly triangular laminae (ca. 160 x $110 \mathrm{~cm}$ ). In each individual, the mature stem bears up to 10 laminae, that will form large coverage at maturity. In most of the examined quadrats, Pteridium caudatum grew and formed a dense ticket.

For number of plot in which species occur, the highest value was Blechnum orrientale (Blechnaceae). Therefore, the frequency value of Blechnum orrientale was the highest in road site. In this study, it was found solitary under the coverage of other pteridophyte. The study of Kumar et al. (2015) also showed that Blechnum orrientale was commonly found at road side, or other exposed and drier area. 

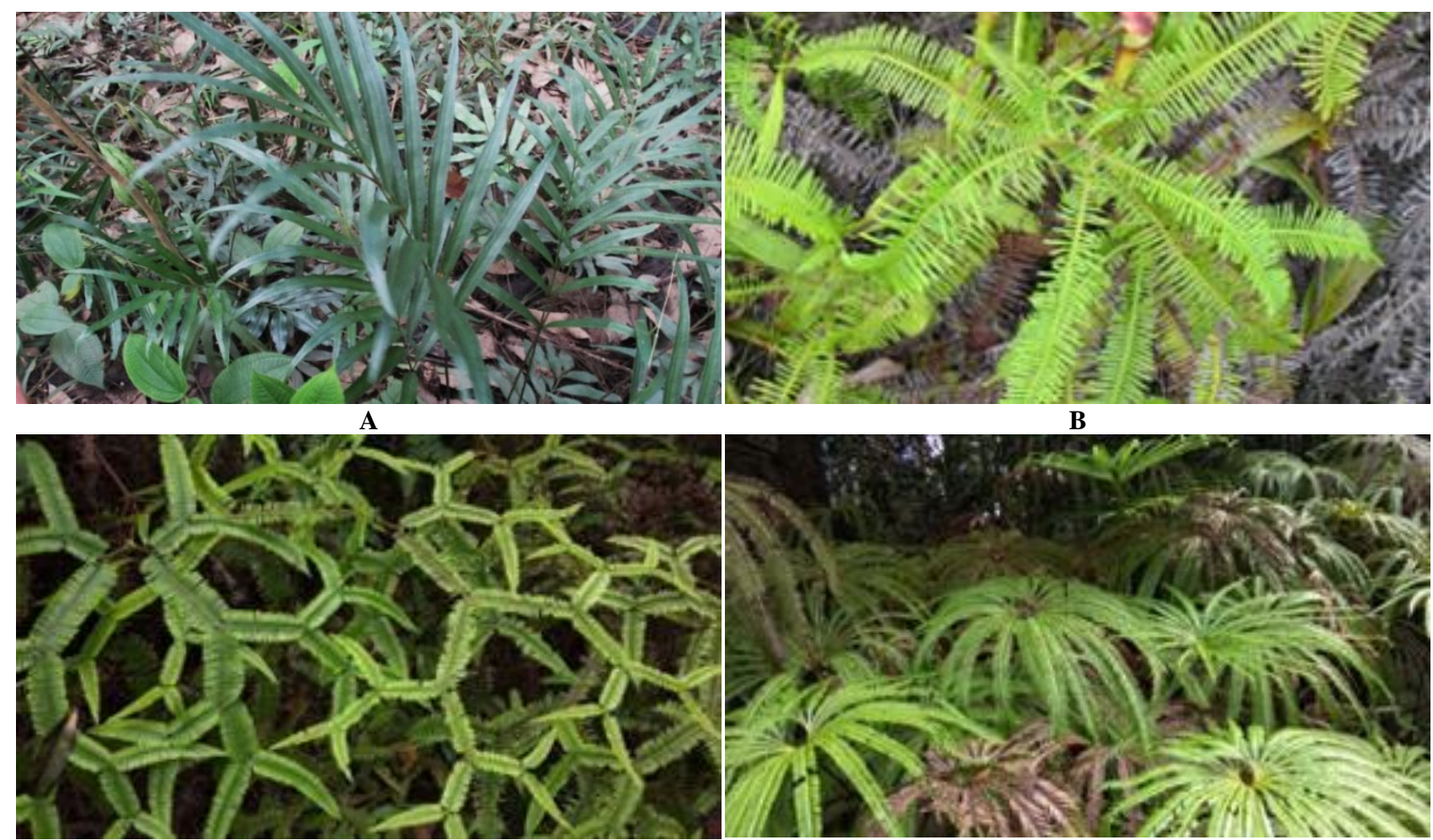

B

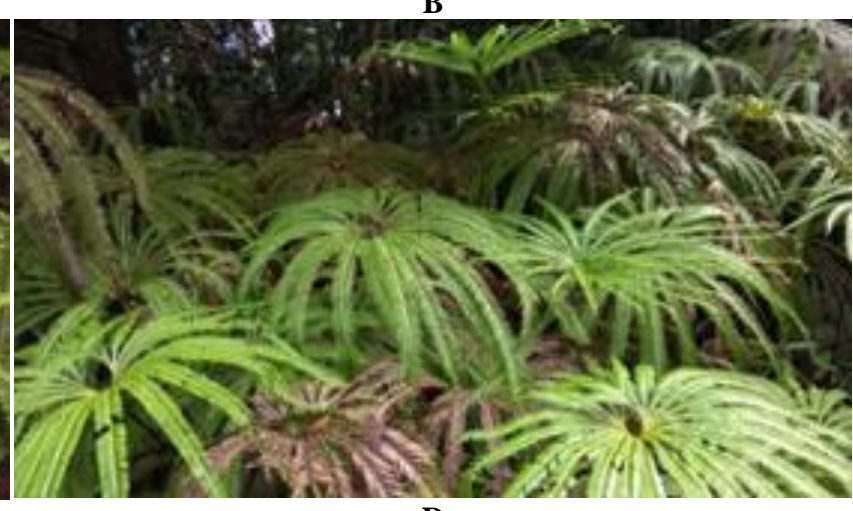

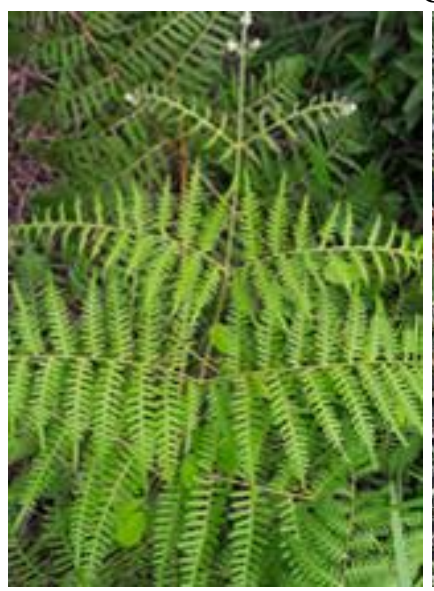

$\mathbf{E}$
C

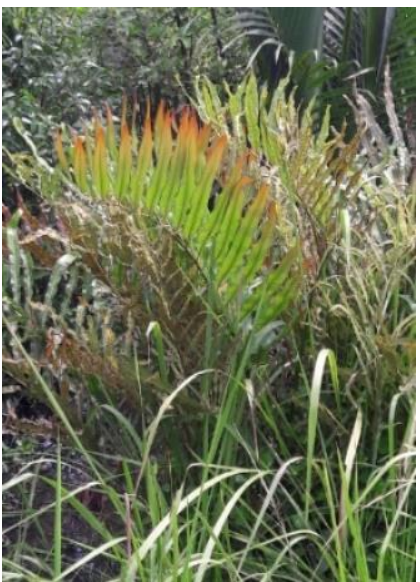

$\mathbf{F}$

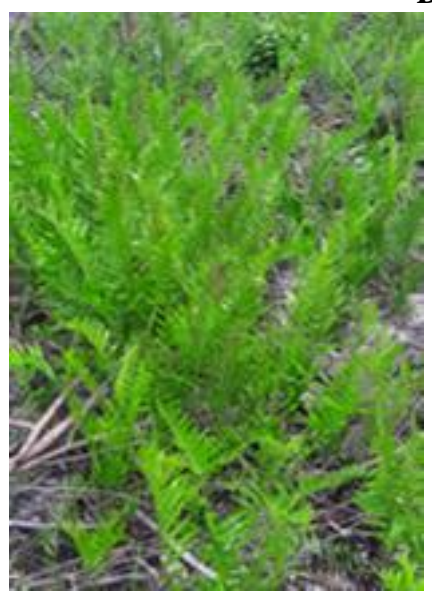

$\mathbf{G}$

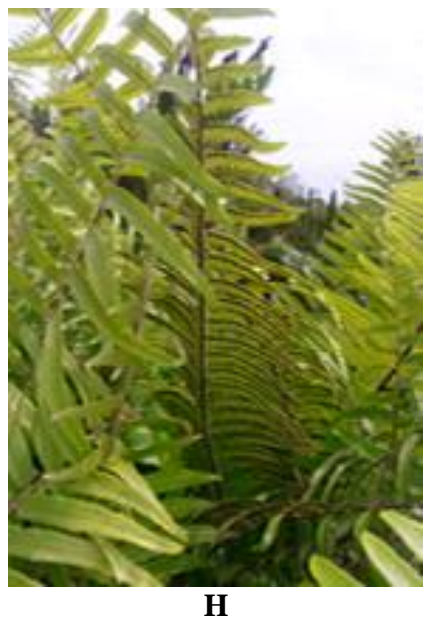

Figure 4. Morphology of some pteridophyte species in Karimun Besar Island. A. Taenitis blechnoides, B. Dicranopteris linearis, C. Sticherus truncatus, D. Matonia pectinate, E. Pteridium caudatum, F. Achrosticum aureum, G. Blechnum serrulatum, H. Nephrolepis hirsutula

\section{Coastal area}

A total of 12 pteridophyte species were recorded at coastal habitat type. These species belong to seven families, i.e., Gleicheniaceae (1 species), Aspleniaceae (1 species), Blechnaceae (3 species), Dentaedtiaceae (1 species), Nephrolepidaceae (1 species), Pteridaceae (3 species) and Lygodiaceae (2 species). Figure 3E shows the structure and composition of pteridophytes in this habitat type. It shows that Achrosticum aureum (Peridaceae) (Figure 4F) had the highest number of plot, coverage, dominance and frequency. At this study site, Acrostichum aureum grew up to $3 \mathrm{~m}$ or more in height, the sprout can be easily grow from rhizome and form dense thicket at maturity (Baba et al., 2013; Ragavan et al. 2014; Kimura et al. 2017). The habit of mature individual of Achrosticum aureum has ca. 2.5-3 $\mathrm{m}$ in diameter or more, and will form a large coverage of an area and give a high dominance value in this study site. This species usually makes a dense colony along the coastal area, and only few solitary individuals were observed. This species is locally known as Paku Laut (Sea Fern) because it is very common fern species at coastal area (Sofiyanti et al. 2019). The study of Medina et al. (1990) showed that Achrosticum aureum is salt tolerant fern species. Therefore, it is common fern at salt marsh (Khan et al. 2013). The occurrence of this species was also recorded at swamp area and mangrove forest (Medina et al. 1990; Khan et al. 2013; Kimura et al. 2017). 
Eventhough Acrostichum aureum had the highest coverage, however the number of individual was lower than Blechum serrulatum (Blechnaceae) (Figure 4G) with up to 135 individuals were recorded in the studied quadrats. This species is solitary with small habit (ca $30-45 \mathrm{~cm}$ in height). Blechnum serrulatum usually occupied landward at drier area. Both Acrosticum aureum and Blechnum serrulatum are commonly found as coastal ferns in Riau Islands Province as reported by Sofiyanti et al. (2019; 2020) in Bengkalis Island and Rangsang Island.

\section{Mined land}

Some areas in Karimun Besar Island were previously used for tin mining and abandoned for many years. The tinmining activities cause environmental change due to the reduction of natural water (Zhang et al. 2018), altering microbial activities (Sheoran et al. 2010) and reduction of soil fertility (Yu et al. 2020). Therefore, ex-mining soil can become plain and barren area if the mining activities are not properly organized (Unanaonwi and Amonum 2017). According to Eddy et al. (2017), the mined land will loss of soil fertility and cause decrease of biodiversity. Most of the ex-tin mining areas in Karimun Besar Island were occupied by lower vegetation such as grasses, herbs and shrubs with few tree plants.

A total of 10 pteridophytes species were recorded in this study site. Nephrolepis hirsutula (Nephrolepidaceae) (Figure $4 \mathrm{H}$ ) showed the highest number of plot, number of individual, density and frequency. Most of Nephrolepis species adapt well to many soil types, full-sun and drought tolerant (Reifner jr and Smith 2015). However, the highest coverage and dominance in this site was Pteridium caudatum (Figure 3F). These species have different habit. Nephrolepis hirsutula shows lower leaf coverage than Pteridium caudatum, due to linear laminae, smaller pinna with mostly erect growth (Sofiyanti et al. 2015). On the other hand, Pteridium caudatum has larger habit, with triangular lamina (up to $1.5 \mathrm{~m}$ in length). Therefore, it will form large coverage, and in some places this bracken fern become weed fern due to its dominant coverage (Olivares et al. 2009).

In conclusion, the primary forest is the habitat type that poses the highest number of species in this study. The forest environment supports the growth of various flora, including fern. The discovery of two fern species from Gleicheniales Order. i.e. Sticherus truncatus (Glecheniaceae) and Matonia pectinata (Matoniaceae) is the important finding of this study. These two species have not been recorded in the previous study of pteridophyte in Riau Islands Province (Sofiyanti et al. 2019). The smallest number of pteridophyte species is found in rubber plantation, due to the impact of alteration of aboveground vegetation. The result of this study showed that the structure and composition of pteridophyte in Karimun Besar Island, Riau Islands Province varied across six habitat types due to the different environmental. The anthropogenic activities decrease the number of species as found in secondary forest and mined land. While the study site with less anthropogenic activities showed higher diversity of pteridophyte.

\section{ACKNOWLEDGEMENTS}

The author acknowledges Directorate General of Higher Education, Ministry of Research and Technology, Indonesia for providing Basic Research Grant. Many thanks to Alfath, Dilah, Alif and the late Papi Soni for the assistance during field works.

\section{REFERENCES}

Amber K, Khan K, Shah A, Lodhi M, Hussain M, Shah G, Khalid R. 2019. A comprehensive survey of floristic diversity evaluating the role of institutional gardening in conservation of plant biodiversity. Intl J Biosci 14 (3): 325-339. DOI: 10.12692/ijb/14.3.325-339.

Aratrakorn S, Thunhikorn S, Donald PF. 2006. Changes in bird communities following conversion of lowland forest to oil palm and rubber plantations in southern Thailand. Bird Conserv Intl 16 (1): 71 82. DOI: 10.1017/S0959270906000062.

Baba S, Chan HT, Aksornkoae S. 2013. Useful Products from Mangrove and other Coastal Plants. ISME Mangrove Educational Book Series No. 3. ISME and ITTO, Japan.

Badshah L, Farrukh H, Zaman S. 2016. Floristic inventory, ecological characteristics and biological spectrum of rangeland, District Tank, Pakistan. Pak J Bot 45 (4): 1159-1168.

Barrington D, Masahiro K, Kunio I, Michael G, Peter H, Hans N, Jefferson P, Ronald V, Maarten C, George Y, Atsushi E, Shunshuke S, Barbara P, Tom R, Norio S, Elisabeth H, Julie B, Alexandr S, Harufumi A, Shigeo M. 2013. Pteridophytes (Lycophytes and Ferns) 2. Flora of China, Edition 1a, Chapter: Pteridophytes,). Missouri Botanical Garden

Bondada B, Cong T, Ma L. 2006. Surface structure and anatomical aspects of Chinese brake fern (Pteris vittata; Pteridaceae). Brittonia $58 \quad$ (3): $217-228$. $\quad$ DOI: $\quad 10.1663 / 0007$ 196X(2006)58[217:SSAAAO]2.0.CO;2.

Della AP, Falkenberg DB. 2019. Pteridophytes as ecological indicators: an overview. Hoehnea 46: E522018. DOI: 10.1590/2236-8906$52 / 2018$.

de Gasper A, Dittrich V, Smith A, Salino A. 2016. A classification for Blechnaceae (Polypodiales: Polypodiopsida): new genera, resurrected names, and combinations. Phytotaxa 275 (3): 191-227. DOI: 10.11646/phytotaxa.275.3.1.

Dittrich V, Alexandre S, Reinaldo M. 2015. The Blechnum occidentale (Blechnaceae, Polypodiopsida) species group in southern and southeastern Brazil. Phytotaxa 231 (3): 201-229. DOI: 10.11646/phytotaxa.231.3.1.

Eddy N, Jennifer F, Umroh, Fournita A. 2017. The Impact of tin mining in Bangka Belitung and its reclamation studies. MATEC Web Conf 101 (6): 04010. DOI: 10.1051/matecconf/201710104010.

Fahreza S, Qotrunnada L. 2011. Study of Pteridophyte diversity and vegetation analysis in Jatikerep Legonlele and Nyamplung, Karimunjawa Island Central Jawa. Jurnal Biologi Indonesia 7 (2): 207-212. [Indonesian]

Go R, Chin LY, Omar H, Mustafa M, Umi M, Haja K. 2012. The distribution of the ferns Gleicheniaceae in Peninsular Malaysia. Acta Biol Malay 1 (1): 18-25. DOI: 10.7593/abm/1.1.18.

Gómez-Noguez F, Pérez-García B, Mehltrete K, Orozco-Segovia A, Irma R. 2016. Spore mass and morphometry of some fern species. Flora 223: 99-105. 10.1016/j.flora.2016.05.003.

Hidayat MH, Endris WM, Dwiyanti Y. 2008. Effect of a rubber plantation on termite diversity in Melawi, West Kalimantan. Indonesia Agric Nat Resour 2 (5): 439-444. DOI: 10.1016/j.anres.2018.10.016.

Hortal J, Triantis KA, Meiri S, Bault E, Sfenthourakis S. 2009. Island species richness increases with habitat diversity. Am Nat 174 (6): 113. DOI: $10.1086 / 645085$

Jayakumar S, Seong K, Joon H. 2011. Floristic inventory and diversity assessment-a critical review. Proc Intl Acad Ecol Environ Sci 1 (3-4): 151-168.

Kato M, Ryoko I. 2011. Leaf anatomy of tropical fern rheophytes, with its evolutionary and ecological implications. Can J Bot 70: 165-174. DOI: $10.1139 / \mathrm{b} 92-022$. 
Kessler M, Smith A, Prado J. 2017. Prodromus of a fern flora for Bolivia. XXVII. Pteridaceae. Phytotaxa 332 (3): 201-250. DOI 10.11646/phytotaxa.332.3.1.

Khan SA, Hossain MA, Panthi S, Asadujjaman M, Hossin A. 2013 Assessment of antioxidant and analgesic activity of Acrostichum aureum Linn. (Family-Pteridaceae). Pharmacol Online 1: 166-171.

Kimura N, Kainuma M, Inoue T, Chan EWC, Tangah J, Baba K, Oshiro N, Okamoto C. 2017. Botany, uses, chemistry and bioactivities of mangrove plants V: Acrostichum aureum and A. speciosum. Isme/Glomis Electron J 15 (1): 1-6.

Konrat M, Naikatini A, Tuiwawa M, et al. 2011. A brief history of the cryptogams of fiji and prospects for the future. Telopea 13 (3): 361 374. DOI: $10.7751 /$ telopea20116028.

Kottapalli S, Krishna H, Venumadhav K, Nanibabu B, Jamir K, Ratnamma B, Jena R, Babara D. 2016. Preparation of herbarium specimen for plant identification and voucher number. Roxburghia 6 (1-4): 111-119.

Kreft H, Walter J, Jens M, Gerold, K, Wilhelm B. 2008. Global diversity of island floras from a macroecological perspective. Ecol Lett 11 (2): 116-27. DOI: 10.1111/J.1461-0248.2007.01129.X.

Kuma M, Shibru S. 2015. Floristic composition, vegetation structure, and regeneration status of woody plant species of Oda Forest of humbo carbon project, Wolaita, Ethiopia. J Bot 5: 1-9. DOI: $10.1155 / 2015 / 963816$

Kumar, Syafiq AM, Ruhaiyem Y, Shahnaz M. 2015. Blechnum orientale Linn.: an important edible medicinal fern. Dash Gouri Intl J Pharmacog Phytochem Res 7 (4): 723-726.

Lan G, Wu Z, Bangqian C, Guishui X. 2017. Species diversity in a naturally managed rubber plantation in Hainan Island, South China. Trop Conserv Sci 10: 1-7. DOI: 194008291771242.

Lashin G. 2012. Palynological studies of some species of Aspleniaceae Pteridophyta. Am J Plant Sci 3 (3): 397-402. DOI: 10.4236/ajps.2012.33048.

Liu F, Frederic B, Allard D, Jin X, Andrieu B, Burger P, Hemmerlé M, Comar A. 2017. A method to estimate plant density and plant spacing heterogeneity: application to wheat crops. Plant Methods 13 (1): 1-11. DOI 10.1186/s13007-017-0187-1.

Marrs RH, Watt AS. 2006. Biological flora of the British Isles: Pteridium aquilinum (L.) Kuhn. J Ecol 94 (6): 1272-1321. DOI: 10.1111/j.13652745.2006.01177.x.

Medina E, Elvira Q, Marianne P, Ariel L. 1990. Soil salinity, sun exposure, and growth of Acrostichum aureum, the mangrove fern. Bot Gaz 151 (1): 141-159. DOI: 10.1086/337803.

Mir SA, Mishra AK, Pala SA, Reshi ZA, Sharma MP. 2015. Ferns and fern allies of District Shopian, Kashmir Valley, India. Biodiversitas 16 (1): 27-43. DOI: 10.13057/biodiv/d160105.

Olivares E, Peña E, Benítez M. 2009. Pteridium caudatum (L.) Maxon behaves as a potassium plant and accumulates aluminum in the subterranean organs. Am Fern J 97 (2): 81-94. DOI: 10.1640/00028444(2007)97[81:PCLMBA]2.0.CO;2.

Palys T. 2008. Purposive sampling. In: Given LM (eds) The Sage Encyclopedia of Qualitative Research Methods. (Vol. 2). Sage, Los Angeles.

Perrie LR, Wilson RK, Shepherd LD, Ohlsen DJ, Batty EL, Brownsey PJ, Bayly MJ. 2014. Molecular phylogenetics and generic taxonomy of Blechnaceae ferns. Taxon 63 (4): 745-758. DOI: 10.12705/634.13.

Pia H, Konrad M. 2016. Effects of rubber cultivation on biodiversity in the Mekong Region. CAB Reviews 10: 1-7. DOI: 10.1079/PAVSNNR201510044.

Pigg K, Rothwell GW. 2001. Anatomically preserved Woodwardia virginica (Blechnaceae) and a new Filicalean fern from the Middle Miocene Yakima Canyon flora of Central Washington, USA. Am J Bot 88 (5): 777-87. DOI: $10.2307 / 2657030$.

Piggott AG. 1996. Fern of Malaysia in Color. Tropical Press Sdn.Bhd, Malaysia.

Punchi-Manage R, Getzin S, Wiegand T, Kanagaraj R, Gunatilleke CVS, Gunatilleke AUN, Wiegand K, Huth A. 2013. Effects of topography on structuring local species assemblages in a Sri Lankan mixed dipterocarp forest. J Ecol 101 (1): 149-160. DOI: 10.1111/1365 2745.12017

Qi Y, Yang Y. 1999. Topographic effect on spatial variation of plant diversity in California. Geogr Inf Sci 5 (1): 39-46. DOI: $10.1080 / 10824009909480512$
Ragavan P, Saxena A, Mohan PM, Ravichandran K. 2014. A hybrid of Acrostichum from Andaman and Nicobar Islands, India. ISME/GLOMIS Electron J 12: 9-14.

Ramirez-Garcia J, Almendros P, Quemada M. 2012. Ground cover and leaf area index relationship in a grass, legume and crucifer crop. Plant Soil Environ 58 (8): 385-390. DOI: 10.17221/195/2012-PSE.

Riefner JrR, Smith AR. 2015. Nephrolepis cordifolia (Nephrolepidaceae) naturalized in southern California (U.S.A.): With notes on unintended consequences of escaped garden plants. J Bot Res Inst Tex 9 (1): 201212.

Rolleri C, Prada C, Gabriel G, Jose M, Passarelli L, Ciciarelli M. 2010. Morphology of the sporophyte and gametophyte of the swamp fern, Blechnum serrulatum (Blechnaceae, Pteridophyta). Aust J Bot 58 (6): 508-518. DOI: 10.1071/BT09238.

Rothfels CJ, Sundue MA, Kuo LY, Larsson A, Kato M, Schuettpelz E, Pryer KM (2012). A revised family-level classification for eupolypod II ferns (Polypodiidae: Polypodiales). Taxon 61 (3): 515-533. DOI: 10.1002/tax.613003.

Russell AE, James R, Vitousek PM. 1998. The ecology of the climbing fern Dicranopteris linearis on windward Mauna Loa, Hawaii. J Ecol 86 (5): 765-779. DOI: 10.1046/j.1365-2745.1998.8650765.x.

Schneider H, Eric S. 2016. Systematics and evolution of lycophytes and ferns. J Syst Evol 54: 561-562. DOI: 10.1111/jse.12231.

Schulz BK, William A. Bechtold, Zarnoch SJ. 2009. Sampling and Estimation Procedures for the Vegetation Diversity and Structure Indicator. Gen. Tech. Rep. PNW-GTR-781. U.S. Department of Agriculture, Forest Service, Pacific Northwest Research Station, Portland, OR. DOI: 10.2737/PNW-GTR-781.

Sheoran AS, Sheoran, Poonia P. 2010. Soil reclamation of abandoned mine land by revegetation: a review. Intl J Soil Sediment Water 3 (2): 13.

Singh D, Slik JWF, Jeon Y, Tomlinson KW, Yang X, Wang J, Kerfahi D, Porazinska D, Adam JM. 2019. Tropical forest conversion to rubber plantation affects soil micro-\& mesofaunal community \& diversity. Sci Rep 9: 5893. DOI: 10.1038/s41598-019-42333-4

Sofiyanti N, Iriani D, Fitmawati, Marpaung AA. 2019a. Morphology, palynology, and stipe anatomy of four common ferns from Pekanbaru, Riau Province, Indonesia. Biodiversitas 20 (1): 327-336 DOI: 10.13057/biodiv/d200138.

Sofiyanti. N., Isda MN, Juliantari, E.Suriatno R, Pranata S. 2019b. The inventory and spore morphology of ferns from Bengkalis Island, Riau Province, Indonesia. Biodiversitas 20 (11): 3223-3236 DOI: 10.13057/biodiv/d201115.

Sofiyanti N, Marpaung AA, Suriatno R, Pranata S. 2020. Jenis-jenis tumbuhan paku di Pulau Rangsang, Kepulauan Meranti, Riau dan karakteristik morfologi-palinologi. Jurnal Biologi Tropis 20 (1): $102-$ 110. DOI: 10.29303/jbt.v20i1.1711. [Indonesian]

Unanaonwi OE, Amonum JI. 2017. Effect of mining activities on vegetation composition and nutrient status of forest soil in Benue cement company, Benue State, Nigeria. Intl J Environ Agric Biotechnol 2 (1): 297-305. DOI: 10.22161/ijeab/2.1.39297.

Venkatachalam P, Geetha N, Palanivel S, Thulaseedharan A. 2013. Natural rubber producing plants: An overview. Afr J Biotechnol 12 (12): 1297-1310. DOI: 10.5897/AJBX12.016.

Wang Q, Punchi-Manage R, Lu Z, Franklin SB, Wang Z, Li Y, Chi X, Bao D, Guo Y, Lu J, Xu Y, Qiao X, Jiang M. 2017. Effects of topography on structuring species assemblages in a subtropical forest. J Plant Ecol 10 (3): 440-449. DOI: 10.1093/jpe/rtw047.

Yu X, Mu C, Zhang D. 2020. Assessment of land reclamation benefits in mining areas using fuzzy comprehensive evaluation. Sustainability 12 (5): 1-20. DOI: 10.3390/su 12052015.

Zhang GM, Liao WB, Ding WY, Lin YX, Wu ZH, Zhang XC, Dong SY, Prado J, Gilbert JG, Yatskievych G, Ranker TA, Hooper EA, Alverson ER, Metzgar JS, Funston AS, Masuyama S, Kato M. 2013. Pteridaceae. In: Wu ZY, Raven PH, Hong DY (eds) Flora of China, Vol. 2-3 (Pteridophytes). Science Press, St. Louis: Missouri Botanical Garden Press, Beijing.

Zhang Y, Zou XJ, Xu, CF, Yang QS. 2018. Decoupling greenhouse gas emissions from crop production: a case study in the Heilongjiang land reclamation area, China. Energies 11 (1480): 1-13. DOI: 10.1016/j.energy.2018.05.003. 